\title{
The Education of an English Professor: The Biographical Narrative
}

\author{
Heriberto González Valencia ${ }^{1}$, Jakeline Amparo Villota Enríquez ${ }^{1} \&$ Lizeth Ramos Acosta $^{1}$ \\ ${ }^{1}$ Education Faculty, Santiago de Cali University, Cali, Valle, Colombia \\ Correspondence: Heriberto González Valencia, Education Faculty, Santiago de Cali University, Cali, Valle, \\ Colombia. Tel: 57-313-720-7896. E-mail: hery77@hotmail.com
}

\author{
Received: January 5, 2018 Accepted: March 22, 2018 Online Published: March 24, 2018 \\ doi: $10.5539 /$ elt.v11n4p101 URL: http://doi.org/10.5539/elt.v11n4p101
}

\begin{abstract}
This article is the result of a qualitative research following the characteristics of hermeneutical research aims to understand the training process of the English university professor, taking into account factors that affect and surround the social, economic, and cultural environment; in which the experience and the story of life, shape the professor. A historicity that allows the subject to be an actor of her own life, and from her experiences narrated, it is analyzed and a training path by which the subject under study obtained academic and life skills. All times and spaces in which the professor is exposed are interpreted to understand the whole process of training. Finally, it is evidenced how the professor's training transcends beyond a simple classroom. The experience of life, lifestyle, family background, socio-cultural context are inseparable part of the training processes.
\end{abstract}

Keywords: education, narration, experience, biographical method, English professor

\section{Introduction}

It is an imminent necessity to improve the pedagogical training of the professors, in order to offer a better preparation to the students in universities. The quality of the teaching-learning process will always be linked to the transformation, life and experience of the university professor. Higher education should aim at the quality of the teaching staff, the students and the institution in all its university environment. According to Castro \& Arboleda (2017), educational reforms can be seen as an opportunity for improvement.

In order for higher institutions in Colombia to meet their academic goals, they require trained professors, and not only professors with scientific knowledge. Professors must know how to teach what it contributes to improving the needs of a society. Zambrano (2002) says "the educable subject requires precise, tangible and intangible instruments. One of them is, precisely, knowledge."

In the professionalization of the university professor, the scientific training and the pedagogical formation must be united in order to achieve the improvement of the professional work. In higher education the thought of a lifelong education is applicable, since the university professor requires continuous training. According to Gonzalez (2015), professors must keep up with trends in teaching. All these leading to professors as role models motivating students for learning English (Herrera \& Tovar, 2017).

Mitchell and Kerchner (1983) who are cited by Imbernón (2000) mention various stages of a professor's professionalization, which allow us to observe different perceptions of the teaching work and the different training ideas that a university professor can have. These stages are:

"The professor as a worker. Conceives the school as a hierarchical system in which it is the manager or director who says what, when and how the professor should teach, so the tasks of conception and planning are separated from the execution.

The professor as an artisan. Greater responsibility is attributed to the professor to select and apply the teaching strategies. In the training programs, the acquisition of tricks to teach are prioritized over theory and reflection.

The professor as an artist. Personal creativity is emphasized, and the development of a greater degree of the professor autonomy is allowed. The acquisition of the general and professional culture is conditioned and sifted by the institution, personality and individual dynamism.

The professor as a professional. Work by nature is not prone to mechanization. The professor is committed to self-reflection and analysis of the needs of students, and assumes important shares of responsibility in the curricular decisions that are shared." 
On the other hand Uricoechea (1999) in his analysis of the subject educator poses the following types of teachers: the academic professional, the disciplinary teacher, the professional teacher and the part-time teacher.

Educational institutions look for the ideal professor, who possesses all these qualifications and in the search of a quality of teaching and learning, the training of the professor is the primordial way. Rumbo (2000) conceives the university professor as that professor and researcher, who reflects on and from her educational practice, which helps to improve it according to the contextual needs where it develops. And according to Enriquez, De Oliveira and Valencia, (2017) it is important that professors reflect on their teaching ways.

All the statements show how through the times the conception of a model of university professor has been evolving until reaching the point where the training of this has become essential both for the subject and for the society that is waiting for some outgoing subjects of higher institutions with the highest degrees of academic excellence.

Consequently, this research seeks clarity regarding the career and life of a university English professor, through the life story, which gives relevance to her as a subject to reflect on the path traveled in her life. The biographical method used in the hermeneutic approach was used to understand the different training stages of the university English professor; to recognize the sense of the pedagogical practices of the university professor from her life trajectory and to recognize the professor's university training through the discursive, the experience and her narration of life.

\subsection{Training}

The training of the subjects has been a constant concern for every society throughout history. And according to Valencia, Enriquez, \& Agredo, (2017), the challenge of education is becoming more and more challenging, spaces and times have changed, the actors involved in the different training processes have pronounced variants. Salinas, Bennito Crossetti and Carrió (2014) say that the training and professional development of each professor should be considered a permanent task. During different times it is observed how societies have tried to improve in all its aspects; and one of the starting points towards that improvement is the education of the subjects. According to Armando Zambrano (2007) "the ultimate goal of education is training. To educate is to transmit values and principles that are essential for a virtuous life". Every modern society must base its projects of improvement on an excellent education of its subjects.

According to Zambrano (2007), experience is the essence of training, a subject needs a journey through time as an essential part of the training. In education we look forward, while training is looking back, is looking at what the subject has lived and bring it to the present."

Education is not necessarily training, you can become an educated subject without a real training and he can perform work, but the subject will never be trained to perform technical work, training is much more than that.

In the same way for Zambrano (2007), when we talk about a trained subject, we talk about a subject who has undergone a transformation. The true transformation is the essence of training and it never ends. Everything that happens to us in life is experience and this is part of our training.

\subsection{The University Professor and Her Training}

According to Salinas et al. (2014) in our environment, the state of university professor training is not in good health. For a fairly long time it was accepted that the person who had mastery of a science was qualified to exercise the difficult profession of teaching. In some countries, they choose the best professional graduates to be those who pass on those lessons learned in their processes.

The word 'professor' varies with respect to different countries; in most English-speaking countries the professor holds a high rank as department director; in the United States the professor works in the university; while in Latin America, professor is anyone who exercises the work of teaching; at university it is called a university professor.

A professor's training is a constant process of acquisition, structuring and restructuring of knowledge, skills and values for the performance of academic work where institutional support is essential as an accompaniment process. And which is directed to the promotion of student learning through the improvement of the performance of the teaching staff. That is why Perdomo (2014) proposes that the training of a new professor must respond to the individual needs of students, capable of generating alternatives to improve the educational quality in the classroom and the promotion of elements as a transformative strategy that when combined with those of the curricula of the current educational system will produce a pedagogical tool capable of preparing the learner for life. 


\subsection{University in Colombia}

"The speed of changes in contemporary society and scientific and technological advances have implications for the processes of modernization and transformation of higher education institutions, which have a central role in professional training and research" (Díaz, 2000), the transformation and evolution that higher education institutions have had in our country are influenced and at the same time influence the training of higher education professors.

The study of higher education has always been considered as something of great value, although in each era it may have different purposes and reasons, higher education has always been a gateway to an individual and societal improvement. According to Perdomo (2014), universities should be concerned, evaluated and reinvented in order to promote growth alternatives that respond to the social, political and economic dynamics of the country and, in turn, allow it to sustain itself over time with credibility.

\subsection{The Narrative of Life}

The narrative of life gives us the sense of what the university professor is and continues to be through her life experiences. According to Arfuch (2002), the biographical methods in depth delineate a territory, a cartography of the individual trajectory always in search of their collective accents. These methods today occupy a predominant position in qualitative research, in tune with the interest in the voice and experience of the subjects and with the testimonial emphasis. Delory-Momberger (2008) tells us "we do not narrate our life because we have a history; but on the contrary, we have a history because we narrate our life".

The narration of life can be considered as the close connection between what happened and the present. Just as an artist expresses a figure in his canvas that lasts, the story of life is to capture all the life events of the subject on paper, and this is achieved with the realities narrated by the subject, a later analysis of that narration and thus obtain significant results.

\section{Research Methodology}

This research is qualitative, following the characteristics of a hermeneutical research, where interpretation is above explanation. Here the interpretation of signs constitutes the path to understanding.

The objective is to understand the training process of the university English professor through her life's narration, for that reason the use of the biographical method is pertinent in the interpretation of the different moments of life, where all the processes that have a direct impact on the training results of the university professor are exposed. Pruzzo (2012) says that the traces left by the pieces of personal history in social subjects, since they are part of common sense, can be used to interpret or act on reality. Lechner and Abrantes (2014) refer to the biographical method as fascinating and promising, in terms of the results that can be achieved.

In the analysis of this narrative of life, all the moments and spaces to which the professor is exposed are interpreted to understand the integral process of training of the English professor, taking into account the social, cultural, economic, political and familiar. Sanmartín (2003) tells us that biographical research is essentially a phenomenological description that requires four procedural skills in the researcher: observing, listening, comparing and writing.

In the research process, grids are worked on that keep us focused on the topics of the research line, which allows us a constant analysis of data and a construction of the theoretical framework used to compare the training proposal of the university professor in our academic environment and thus obtain an optimal result in our research.

\section{Data Presentation}

The professor is a 36-year-old woman from the small town of Palmira, Valle, Colombia. Single woman and without children. Graduated from Universidad del Valle, with a Degree in Modern Languages, a Specialization and a Master's Degree in Teaching Higher Education. She works as an English professor in a university where she is always looking for the improvement of teaching-learning processes of English as a foreign language.

According to the theoretical framework, where a journey is made about the training of the university professor and based on hermeneutical research, as interpretation of signs, we see how the life trajectory of the professor in each time and space becomes a pillar of the investigative interpretation of how the education of the university professor occurs from the perspective of the training discourses and what is the impact in the field of higher education through the narration of her biography.

In this interpretation of the narrative of life of the professor, all the moments that influenced the professor's training are analyzed, those moments that without having great transcendence in space and real time become 
determinant over time to achieve a transformation of the professor in her performance as an educator of the future members of a society.

BIOGRAM - Life map - Identification of significant moments

\begin{tabular}{|c|c|c|c|c|}
\hline MOMENT & FAMILY & SOCIO/CULTURAL & ECONOMIC & POLITIC \\
\hline Childhood 1 & $\begin{array}{l}\text { Complete family } \\
\text { environment, } \\
\text { mother, father, } \\
\text { sister and brother. }\end{array}$ & $\begin{array}{l}\text { Contrast between their family } \\
\text { environment of middle / high } \\
\text { class and the social / cultural } \\
\text { levels of their classmates, } \\
\text { children of the sugarcane } \\
\text { workers. }\end{array}$ & Middle/high class. & $\begin{array}{l}\text { Educational } \\
\text { level at public } \\
\text { and private } \\
\text { schools. }\end{array}$ \\
\hline Childhood 2 & $\begin{array}{l}\text { The same as } \\
\text { childhood } 1 .\end{array}$ & $\begin{array}{l}\text { Medium / high socio / cultural } \\
\text { context due to the change to } \\
\text { one of the most recognized } \\
\text { schools in the city. }\end{array}$ & Middle/high class. & $\begin{array}{l}\text { The same as } \\
\text { childhood } 1 .\end{array}$ \\
\hline Adolescence & $\begin{array}{l}\text { A family nucleus } \\
\text { very strengthened } \\
\text { over the years. }\end{array}$ & $\begin{array}{l}\text { The socio / cultural level is a } \\
\text { mixture of different types } \\
\text { given to the different study } \\
\text { partners to which she is } \\
\text { exposed in the public } \\
\text { university in which she was } \\
\text { enrolled. }\end{array}$ & $\begin{array}{lr}\text { Economic } & \text { level } \\
\text { with } & \text { ample } \\
\text { possibilities } & \text { of } \\
\text { higher education. }\end{array}$ & $\begin{array}{l}\text { Changes in } \\
\text { higher education } \\
\text { at the public } \\
\text { university in } \\
\text { Colombia. }\end{array}$ \\
\hline Work & $\begin{array}{l}\text { Although she } \\
\text { begins to be much } \\
\text { more independent } \\
\text { due to her work, the } \\
\text { family continues to } \\
\text { be an essential } \\
\text { support base in her } \\
\text { performance. }\end{array}$ & $\begin{array}{l}\text { The professor starts working } \\
\text { in a high socio-cultural level } \\
\text { school, and after a few years } \\
\text { she starts working in a private } \\
\text { university, where the socio / } \\
\text { cultural level is low / medium. }\end{array}$ & $\begin{array}{l}\text { Her work makes her } \\
\text { an active participant } \\
\text { in a medium / high } \\
\text { economic level. }\end{array}$ & $\begin{array}{l}\text { There are } \\
\text { changes that } \\
\text { affect higher } \\
\text { education } \\
\text { throughout the } \\
\text { Colombian } \\
\text { territory. }\end{array}$ \\
\hline $\begin{array}{l}\text { Postgraduate } \\
\text { study }\end{array}$ & $\begin{array}{l}\text { The family, } \\
\text { especially her } \\
\text { father, has always } \\
\text { been part of } \\
\text { inspiration ro } \\
\text { undertake new } \\
\text { challenges. }\end{array}$ & $\begin{array}{l}\text { She is exposed to a different } \\
\text { thinking in terms of socio / } \\
\text { cultural levels. (French } \\
\text { thinking) }\end{array}$ & $\begin{array}{l}\text { The help of the } \\
\text { scholarship offered } \\
\text { by the university } \\
\text { helps a lot in } \\
\text { difficult times to } \\
\text { carry out } \\
\text { postgraduate studies } \\
\text { in the country. }\end{array}$ & $\begin{array}{l}\text { The new } \\
\text { policies } \\
\text { regarding } \\
\text { teaching in } \\
\text { higher education } \\
\text { and the training } \\
\text { of teachers } \\
\text { become more } \\
\text { rigid. }\end{array}$ \\
\hline
\end{tabular}

\section{Conclusions}

From the narration of the professor, the researcher listens, organizes and interprets the moments of life, which have given a form, to the subject. Throughout history the narrations have been used to capture different historical moments, that is why in this biography of the English professor, her life narration and the biographical data in her resume become vitally important in the understanding of her training process as a university professor, since the accumulation of all that experience shows us how essential the moments or stages of each process can be in the life of a human being as an influence on performance in a society.

In this research, the life experience of the professor plays a definitive role in her training. Academic growth is something that takes place as a result of the academic processes in which she transcends, but the real training or in better words transformation, occurs with her life experience.

The narration of the professor interviewed shows how different socio-cultural experiences in different socio-economic environments help her to see the reality of her own students' lives, and thus she achieves an 
analysis in her work environment, which leads to a human point to allow the integral development of her students, making this professor not only a guide within the classroom, but a trainer of human beings for the society in which they live.

It is also observed how through the different moments and spaces of the life of the professor, she undergoes changes, both academic and personal, in order to see a true academic and life transformation which has a total impact on the improvement of the quality that students who are exposed to her teaching finally receive.

The first years of university study frame the professor in an academic context which she chooses to follow and from that moment she intends to reach the highest level. Following these moments, the first working years lead her and show her that her journey through life until that moment marks many of the routes to follow in her daily academic work.

The evidence that is expressed in this document after the exhaustive interpretation using the biographical method, gives us an answer to the problem posed as to how the training of the university professor occurs from the perspective of the training discourses and which is the impact of the training of the university professor in the field of higher education through the narration of her biography, and shows how a lifetime of experiences and academic, personal and work experiences are a significant part in the overall development of the English professor with all the responsibilities that you have when you are part of a society.

It can be affirmed that two of the most significant influences in the whole process of the training of the English professor are evident in the crossings of information regarding the familiar and the socio-cultural. The example and support of her father through all the moments of the professor's life are shown and corroborated as an essential part of her training. Regarding the socio-cultural influence, the transfer of the professor to two completely opposite worlds regarding the social, cultural, economic, shows a very significant realities and mark a few essential ways in the educational environment that is handled in the world of Education.

The different scenarios and the journey through different moments of life of the English professor are the evidences of a training, more understood as a true transformation of the being. This transformation as a result of academic, life and work experiences that lead the professor to obtain all those significant achievements.

With all the information gathered in this research, you can see how the training of the English professor as a foreign language transcends beyond a simple class. The experience of life, the way of life, the family context, the socio-cultural context, are an inseparable part of the training of the university professor. The collection of experiences in much defined moments and spaces shape the individual and they outline a path to follow in her walk for life and in that goal of being better every day.

\section{References}

Arfuch, L. (2002). El espacio biográfico, Dilemas de la subjetividad contemporánea. Fondo de cultura económica.

Castro-Garcés, A. Y., \& Arboleda, A. (2017). Bridging the Gap between Curriculum Planning Policies and Pre-service Teachers' Needs. English Language Teaching, 10(12), 50. https://doi.org/10.5539/elt.v10n12p50

Delory-Momberger, C. (2008). Lo biográfico: una categoría antropológica. Compilación biográfica y formación de Sarria M. Martha et all.

Diaz Villa, M. (2000). La formación de profesores en la educación superior Colombiana: Problemas, Conceptos, Políticas y Estrategias.

Enriquez, J. A. V., De Oliveira, A. M. P., \& Valencia, H. G. (2017). What Mathematic Teachers Say about the Teaching Strategies in the Implementation of Tasks. English Language Teaching, 11(1), 1. https://doi.org/10.5539/elt.v11n1p65

González, H. (2015). La integración de la tecnología como herramienta significativa en la enseñanza del inglés como lengua extranjera. Revista Horizontes Pedagógicos, 17(1), 53-66.

Herrera-Mosquera, L., \& Tovar-Perdomo, A. (2017). Personal and Academic Aspects that Contributed to the Development of the English Language Competence of Students from a Language Teacher Education Program. English Language Teaching, 10(10), 140. https://doi.org/10.5539/elt.v10n10p140

Imberón, F. (2000). La formación y desarrollo profesional del profesorado universitario. Hacia una nueva culturta profesional. Editorial Graó. Barcelona.

Lechner, E., \& Abrantes, P. (2014). La investigación (auto) biográfica en Portugal: un mapeo y dos estudios. Revista Mexicana de investigation educativa, 19(62), 859-883. 
Perdomo, J. A. (2014). La Universidad y la actualización para tutores basada en Coaching. Revista Horizontes Pedagógicos, 16, 123-141.

Pruzzo, V. (2012). La transformación de la formación docente. Praxis Educativa, 3(3), 69-76.

Rumbo A. B. (2000). La profesionalización de la docencia universitaria. Revista curriculum, 14, 133-143.

Salinas, J., De Benito Crossetti, B., \& Carrió, A. L. (2014). Competencias docentes para los nuevos escenarios de aprendizaje. Revista interuniversitaria de formación del profesorado, 79, 145-163.

Sanmartín, R. (2003). Observar, escuchar, comparar, escribir. La práctica de la investigación cualitativa, Barcelona, Ariel Antropología.

Uricoechea, F. (1999). La profesionalización académica en Colombia. Historia, estructura y procesos. Tercer Mundo Editores, Bogotá.

Valencia, H. G., Enríquez, J. A. V., \& Agredo, P. M. (2017). Strategies Used by Professors through Virtual Educational Platforms in Face-To-Face Classes: A View from the Chamilo Platform. English Language Teaching, 10(8), 1. https://doi.org/10.5539/elt.v10n8p1

Zambrano Leal, A. (2002). Pedagogía, educabilidad y formación docentes. Santiago de Cali: Nueva Biblioteca Pedagógica.

Zambrano Leal, A. (2007). Formación, experiencia y saber. Editorial Magisterio.

\section{Copyrights}

Copyright for this article is retained by the author(s), with first publication rights granted to the journal.

This is an open-access article distributed under the terms and conditions of the Creative Commons Attribution license (http://creativecommons.org/licenses/by/4.0/). 